RUDIGER DORNBUSCH

Massachusetts Institute of Technology

HOLGER WOLF

Massachusetts Institute of Technology

\title{
Economic Transition in Eastern Germany
}

ONLY A FEW months after the Berlin Wall came down in the fall of 1989, the West German government decided that it should establish a currency union with East Germany. ${ }^{1}$ Shortly thereafter, the West and East German governments agreed to economic, monetary, and social union. By July 1991, the State Treaty, which formalized the union, came into force; by October, the German Democratic Republic ceased to exist. Left on the agenda is the task of rebuilding the eastern German economy. But by now, the initial enthusiasm accompanying the fall of the wall has all but vanished. Today, western Germans balk at the vast cost of reconstructing the East and even doubt that the task can be done. In eastern Germany, which functions as a welfare colony of its richer, western neighbor, the initial support for the market economy has been replaced by cynicism, if not outright hostility. Calls for an even more active role of the state in sustaining eastern German industry increasingly gain adherents.

The progress and the obstacles that lie ahead are the subject of this paper. George Akerlof and others opened the subject with a diagnosis of the transition problem (they called it a Keynesian depression) and advanced a bold policy proposal: an across-the-board, substantial labor

For helpful comments, we are indebted to our discussant, Lewis Alexander, and to members of the Brookings panel, especially Lawrence Summers, William Nordhaus, and Robert Barro.

1. Throughout this paper, West Germany and "the West" and East Germany and "the East" are used synonymously. 
subsidy. ${ }^{2}$ We pick up the topic from a somewhat different perspective. We ask what makes eastern Germany special compared to other transition economies. First we provide an update on the progress of economic union. Then we examine estimates of how rapidly eastern Germany can expect to grow. We address the now popular question of how long it will take eastern Germany to reach western German standards of productivity.

We are optimistic about the prospects for eastern German growth. But can one be equally optimistic about western Germany, which must foot the bill? The concluding section addresses that question.

\section{Current Economic Conditions in Eastern Germany}

The availability of western German support provides eastern Germany with the most favorable fundamentals for a rapid transition. Partly offsetting these advantages is the presence of a rich brother that will underwrite the social security system, thus creating an incentive to increase wages ahead of productivity. This section reviews the interplay of these factors since 1989. The discussion serves as a background for an evaluation of the growth opportunities in unified Germany. ${ }^{3}$

\section{Institutions}

The eastern German experience is unique among transition economies because the country inherited not only a complete set of institutions appropriate to advanced industrial countries, but also access to experienced administrators to run those institutions. Among these imports are a legal system, including a body of commercial law, a system of property rights, and a set of courts; a social system, including unemployment compensation and a pension system with immediate entitlements for qualified recipients; a hard currency, a system of public finance, and a banking system with branches that opened virtually immediately after

2. Akerlof and others (1991).

3. In 1991, eastern Germany's GDP was 7.4 percent of western Germany's; labor productivity was 29.6 percent of western German levels; and population was about one-quarter of western Germany's. Statistiches Bundesamt Wiesbaden, Fachserie 18, Reihe 1.1, 1991. 
unification; decentralized government authority; accounting systems; free trade access throughout Europe; and strong political parties.

Two special features facilitated the introduction of these institutions. First, unification created a legal union and thus dispensed with the sovereignty issue that typically stands in the way of the wholesale importing of institutions. Second, the common institutional history meant that the new institutions could build on existing structures in many cases.

Is the importing of institutions in fact a blessing? One could argue that a less complicated legal system-particularly in the area of property rights-or somewhat less stringent conditions for construction permits might have been more suitable for a rapid transition. On balance (except in the area of restitution of property to previous owners), the gains potentially to be obtained from fine tuning the imported legal institutions clearly outweigh the disadvantages. The sheer existence of marketproven institutions greatly enhances the prospects for privatization. Were eastern Germany trying to create its own institutions, as Ukraine is attempting to do, results would occur much more slowly and probably be far worse. Specifically, home-grown institutions carry a risk of populism that could make the business environment unattractive.

In two areas the transition policy clearly failed, however. First, all debts were not eliminated at the outset. Debts mar the balance sheets of firms and banks and complicate the restructuring process and privatization negotiations. A unique opportunity existed to start with a clean slate by canceling enterprise debt; creating public debt to balance bank balance sheets; and retiring debt with the additional revenues obtained by selling enterprises that were debt-free rather than heavily indebted.

The second and more serious difficulty surrounds the treatment of property rights and restitution to previous owners. The decision to allow previous owners to reclaim real estate and assets still stands in the way of a swifter restructuring process. The existence of more than one million claims, and not infrequently five, ten, or even fifteen claimants to the same asset, foreshadows years and years of sorting out the restitution problem-unless a dramatic cut is made. But it may now be too late for such a cut, although some attempts are being made. Priority is being given to new owners who invest. Even that status is not beyond challenge. Property rights that are not clearly defined interfere with efforts to rebuild the economy. The remaining claims on real estate and residential structures stand in the way of steps by current occupants to modernize 
those structures, increasing social expenditures and making migration more attractive.

The approach taken toward restitution offers another special difficulty: it amounts to a de facto expropriation from eastern German citizens, thereby lowering even further their chance of matching western Germans in terms of assets.

In both the treatment of property rights and the cancellation of debts, the Germans' unwillingness to look forward and let bygones be bygones was a grave mistake. ${ }^{4}$

\section{Wages and Productivity}

George Akerlof and his colleagues noted that the debate on conversion in relation to wages largely missed the most essential point- the behavior of unions. ${ }^{5}$ In no time, unions in the West (and in the East) portrayed wage parity as the target and early convergence as the objective, regardless of eastern German productivity levels.

A less favorable conversion rate thus would have led to more wage inflation, but with the same endpoint. Wages ultimately would be the same-either higher in the beginning because of favorable conversion or lower at the start but rising more thereafter. The adjustment might have taken a bit longer, but politics would have been less favorable and inflation would have been more of an issue. An immediate and sharp increase in relative wage dispersion would have added to the troubles. All things considered, wage pressure is a severe problem, but unions and geography, rather than the conversion rate, are to blame. The East could have done without the introduction and integration of unions from western Germany.

Because of the initial conversion and wage increases since unification, eastern German wages in many sectors now exceed 50 percent of western German wage levels. In fact, hourly compensation already exceeds U.S. wages in many sectors, including chemicals, textiles, and electrical machinery. Table 1 provides data on eastern German wages.

While wages have quickly moved to reach half the western German

4. When the time comes for Cuba to leave communism behind, these lessons should be remembered.

5. Akerlof and others (1991). 
Table 1. Wages in Eastern Germany

Percent

\begin{tabular}{ccc}
\hline Sector & $\begin{array}{c}\text { Percent of } \\
\text { value added }^{\mathrm{a}}\end{array}$ & $\begin{array}{c}\text { Percent of } \\
\text { Western }_{\text {German wage }} \mathrm{b}^{\mathrm{b}}\end{array}$ \\
\hline All sectors & $\ldots$ & 50 \\
Manufacturing & 138 & 43 \\
Chemical industry & 211 & 33 \\
Machinery & 102 & 40 \\
Metal & 759 & 49 \\
Garments & 214 & 67 \\
Commerce & $\ldots$ & 54 \\
Construction & $\ldots$ & 74 \\
\hline
\end{tabular}

Source: Wochenbericht 5-6/92 (January 30, 1992), p. 54.

a. Wages as percent of value added are for the second half of 1990 .

b. Wages as percent of western German wages are for 1991 .

level and are on the way to parity, productivity is low relative to western German standards. Exact comparisons are not available, but on the basis of GDP per worker, eastern German productivity is only one-third that of western Germany. Hourly compensation and GDP per worker are shown in table 2. The eastern German productivity level resembles Mexico's or Korea's, while the wage level matches that of the United States and already is ten times greater than that of the neighboring Czech and Slovak Federal Republic. Such a discrepancy is obviously not a recipe for economic success. Overly high real wages were an important source of unemployment in Europe during the 1980s, according to a volume edited by Robert Lawrence and Charles Schultze. ${ }^{6}$ How can eastern Germany escape high unemployment with such an extreme misalignment between productivity and labor compensation?

\section{Employment and Unemployment}

Since the fall of 1989, one out of tirree workers-some 3 million people-have lost their jobs. The largest decline was in the industrial sector; there, more than 1.7 million jobs were lost. In all, jobs were lost in every branch of economic activity. ${ }^{7}$

6. Lawrence and Schultze (1987).

7. For a discussion of the German labor markets, see Scheremet (1992), Scheremet and Schupp (1992), and Franz (1991). 
Table 2. Wages and Productivity in Selected Countries

Index: United States $=100$

\begin{tabular}{lcc}
\hline Country & $\begin{array}{c}\text { Manufacturing } \\
\text { wages }\end{array}$ & $\begin{array}{c}\text { GDP per } \\
\text { worker }\end{array}$ \\
\hline Germany & 146 & 70 \\
Western & $66^{\mathrm{a}}$ & $23^{\mathrm{a}}$ \\
Eastern & 100 & 100 \\
United States & 86 & 65 \\
Japan & 26 & 33 \\
Korea & 25 & 31 \\
Portugal & 12 & 39 \\
Mexico & $7^{\mathrm{a}}$ & 21 \\
Poland & $7^{\mathrm{a}}$ & 30 \\
\hline
\end{tabular}

Sources: Wages are hourly compensation in manufacturing in 1990 in U.S. dollars, from Bureau of Labor Statistics (1991). Estimates of GDP per worker in 1985 international prices from Summers and Heston (1991).

a. Authors' calculation based on 1991 results.

Most of the people who are no longer employed have become unemployed, of course. Table 3 presents more information about unemployed workers in eastern Germany. For a while, short-time work disguised the extent of unemployment, but by January 1992, more than 1.3 million workers were unemployed. Public work programs and continued shorttime work accounted for almost another 1 million jobs. But the labor force declined significantly-by more than 1 million workers-as workers migrated, commuted, or chose early retirement. In addition, the participation rate of females in the labor force-previously the highest in the world-declined significantly.

\section{Output and Transfers}

Since 1989, measured real GDP in eastern Germany has fallen 42 percent. Only toward the end of 1991 did the first fragile signs of a turnaround appear. The drop in real GNP has a number of explanations: the most important are the loss of cost-competitiveness and the dramatic shift of demand to imports, induced by the sudden, unrestricted access to Western goods, coupled with generous income transfers. The complete and radical import liberalization, reinforced by the marketing skills of western German distributors (notably retail chains and mail order 
Table 3. Open and Disguised Unemployment in Eastern Germany, 1991-92

Thousands of workers

\begin{tabular}{lcrc}
\hline & \multirow{2}{*}{1991} & \multicolumn{2}{c}{1992} \\
\cline { 3 - 4 } Employment status & Fourth quarter & January & February \\
\hline Total not at work ${ }^{\mathrm{a}}$ & 2,058 & $\ldots$ & $\ldots$ \\
Unemployed & 1,037 & 1,343 & 1,290 \\
Short-time workers & 1,113 & 521 & 519 \\
Work program & 357 & 394 & 400 \\
Education & 90 & 77 & 103 \\
Others not employed & & & \\
$\quad$ in eastern Germany & & & \\
Migrants & 382 & $\ldots$ & $\ldots$ \\
Commuters & 482 & $\ldots$ & $\ldots$ \\
Early retirees & 661 & $\ldots$ & $\ldots$ \\
\hline
\end{tabular}

Source: Wochenbericht 12-13/92 (March 19, 1992), p. 134, and Monatsberichte der Deutschen Bundesbank, March 1992.

a. In computing the total, figures for short-time workers are weighted by the amount of time spent out of the workplace.

b. The increase in migrants, commuters, and early retirees since fourth quarter 1989 is shown.

houses) led to a situation where imports increased even above the level of GDP, as shown in figure 1. The decline in demand for goods produced in eastern Germany, reinforced by disorganization on the supply side, resulted in a sharp output contraction, especially in industry. (See table 4.)

While output and employment declined dramatically, massive transfers from western Germany to eastern Germany immediately raised the standard of living and started financing the reconstruction. In 1991, these transfers totaled $139 \mathrm{DM}$, an extraordinary three-quarters of GNP in eastern Germany and 5.5 percent of GNP in the West. This is more than twice the percentage of GNP that the United States spent on the Marshall Plan. The Bundesbank estimates that these internal transfers will climb to 180 billion DM in $1992 .^{8}$

Transfers of this magnitude help explain why the collapse in production and the sharp increase in unemployment did not translate into an even worse cumulative depression than in fact has occurred.

8. Monatsberichte der Deutschen Bundesbank, March 1992. 
Figure 1. Real GDP and Trade in Eastern Germany, Third Quarter 1989 to Fourth Quarter 1991

Billions of 1990: $2 \mathrm{H}$ deutsche marks, quarterly rated

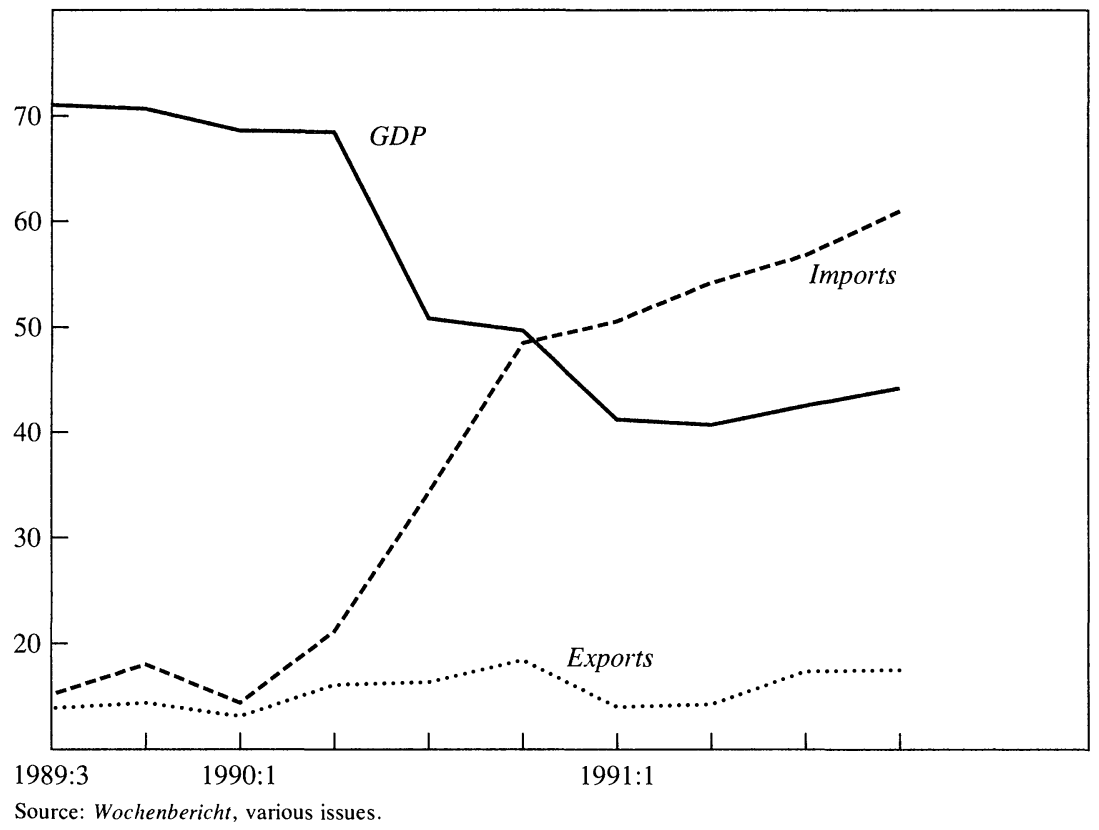

\section{Commuting and Migration}

In eastern Germany today, family incomes equal nearly 55 to 60 percent of western German levels. Nearly 30 percent of the labor force is unemployed, when short-time work and jobs programs are factored in. Migration, or at least commuting, would seem to be an obvious solution to unemployment.

In fact, commuting is flourishing: nearly one-half million eastern German residents work in the West. With an average commuting time of only 40 minutes, this number could double or triple. In western Germany, 39 percent of the labor force commutes; nearly 70 percent of commuters travel 10 to 50 kilometers. ${ }^{9}$ Eastern Germans will find that in the coming years, commuting may strike the best balance between earnings and the cost of living. Commuting doubles earnings without adding the large extra cost of housing in western Germany.

9. See Wochenbericht 3/92 (January 17, 1992), p. 23. 
Table 4. Eastern German Macroeconomic Indicators, 1989-91

Billions of real deutsche marks, except where noted ${ }^{\mathrm{a}}$

\begin{tabular}{lrrr}
\hline \multicolumn{1}{c}{ Indicator } & 1989 & 1990 & 1991 \\
\hline Real GNP & 281.2 & 235.9 & 163.7 \\
Imports & 63.4 & 117.0 & 218.7 \\
Consumption & 155.1 & 164.9 & 173.1 \\
Disposable income & & & \\
(percent of GDP) & $\ldots$ & 79.1 & 112.1 \\
\hline
\end{tabular}

Source: Wochenberict 33/91 (August 15, 1991) and Wochenbericht 7/92 (February 13, 1992). a. The real DM are at constant 1990:2H prices.

Migration decisions reflect cost-benefit analysis involving employment opportunities and income prospects. Akerlof and his colleagues make the point that unemployment is the overriding reason for migration decisions. ${ }^{10}$ This is borne out to some extent by a panel survey in eastern Germany, as shown in table 5 .

Three points emerge from this inquiry. First, few people have concrete plans to move. Second, about half of the males surveyed will contemplate moving in the long term. That is an extremely large number; exactly how to evaluate it is difficult to know. Presumably it means that if things do not work out, then workers may contemplate moving. That is a far cry from actually moving. Finally, further data (not reported) show that about half of employed workers are willing to move. Among homeowners, only one-third are willing to migrate in the medium term.

\section{Privatization}

Eastern German privatization is progressing at an extremely rapid pace. By now, some 30 companies a week are going private. At the outset, the privatization agency, the Treuhand, had to dispense with 9,000 industrial businesses, 45,000 establishments, 20,000 commercial businesses, 7,500 hotels and restaurants, 1,000 pharmacies, and numerous bookshops and cinemas. In addition, the agency was responsible for vast holdings of land and for 3 million jobs. By February 1992, 5,500 industrial firms had been sold (or closed). ${ }^{11}$ As part of the sales strategy,

10. Akerlof and others (1991).

11. In the process of privatization, the giant conglomerates, or Kombinate, were split up, causing the number of firms to increase significantly. 
Table 5. Eastern German Workers' Willingness to Migrate in the Short and Medium Term

Percent of male population below age 49

\begin{tabular}{ccc}
\hline & \multicolumn{2}{c}{ Willingness to migrate } \\
\cline { 2 - 3 } Employment status & Short term & Medium term \\
\hline Total & 4.9 & 50.2 \\
Full-time employed & 4.6 & 47.9 \\
Short-time workers & 2.2 & 46.1 \\
Unemployed & 7.4 & 59.2 \\
Commuters & 9.3 & 61.9 \\
\hline
\end{tabular}

Source: Wochenbericht 5-6/92 (January 30, 1992), p. 60.

potential buyers had to submit employment and investment plans covered by guarantees. To date, the privatization process has led to employment guarantees for more than 1 million workers and investment commitments of DM 140 billion.

Of course, privatization is far from complete. Some 5,000 companies still must be sold. It is only a question of time before most are sold or closed. However, some firms pose difficult regional questions. It is not clear whether the government wants to protect jobs as a regional policy or as just a way to sustain workers' incomes. That problem is no different from the regional problems associated with declining industries in western Germany and other European economies.

The special feature of eastern Germany's privatization is that the overriding majority of industrial firms sold have been bought by foreigners in western Germany and other countries. ${ }^{12}$ Moreover, most firms were sold to enterprises that operate in the same or similar industries. This situation differs radically from one in which domestic residents become owners and managers. The predominance of foreign investment brings with it immediate access to capital, technology, management, markets, and brand names. The privatization mechanism, with its emphasis on selling to the West, thus has provided an immediate and strong infusion of market skills and state-of-the-art technology at the level of the firm.

Banks have played no significant part in the privatization process. But the western German banking system immediately expanded to the

12. However, foreigners have not been the main buyers of shops, restaurants, and pharmacies. 
East on the coattails of the Bundesbank. With a banking system that has secured access to the world capital market in place, the East should not find it difficult to finance further investments in new small and mediumsize firms.

\section{Growth and Convergence}

As the East faces mass unemployment, low productivity, and massive transfers, the question naturally arises where its economy is headed. One of the biggest factors is productivity. Eastern Germany productivity is at about one-third of western German levels. However, in terms of income, the gap is only one-half and narrowing. What are the prospects for productivity improvements? Is it plausible that much of the difference in per capita output between eastern and western Germany can be made up over the next 10 or 15 years? If not, transfers would have to last indefinitely or major migration would be the response to lasting differences in opportunity.

Two possibilities exist. One is that the situation of eastern Germany is no different from any other catch-up situation and thus follows the "law of convergence" at the rate of 2 percent per year presented by Robert Barro and Xavier Sala-i-Martin. ${ }^{13}$ Another possibility is that the Eastern European transition economies in general and the eastern German situation in particular is characterized by a number of special advantages. Specifically, high levels of education and geographic proximity may facilitate the transfer of skills and technology. If so, the opening of Eastern Europe presents a different situation from countries like Brazil or Malaysia that are catching up to the industrialized world. Moreover, if political integration removes risk factors and information costs and firms receive massive subsidization, why shouldn't investment rates rise extravagantly?

Finally, we should note that if productivity grows rapidly, unemployment almost certainly will increase sharply. Thus good productivity performance in the early years is bound to be a mixed blessing for Eastern European economies.

13. Barro and Sala-i-Martin (1991). 


\section{Pessimistic Views of Convergence}

Barro and Sala-i-Martin have offered a dismal outlook for the convergence of eastern and western Germany. Drawing on their findings of convergence in a large cross section of regions and countries, they conclude that "it would take 35 years for half of the initial East-West gap to be eliminated. Thus, the results extrapolated from our findings for regions of the United States and Europe and for a variety of countries imply that East Germany's achieving 'parity' in the short run is unimaginable." 14

Barro further spells out the dismal scenario when, based on the same evidence, he observes that the "growth advantage (which will decline over time as the East closes upon the West) means that it will take . . . about 70 years to eliminate three-quarters of [the gap]. If so, the East would eventually catch up to the West, but in a couple of generations rather than a couple of years or a couple of decades." 15

A starting point for the discussion is a mechanical assessment of the relation between average compound growth and the number of years to raise productivity (measured as GDP per capita) in eastern Germany to some fraction of productivity in western Germany. Let the initial ratio of productivities between eastern and western Germany be $x_{0}=0.3$. Let $x_{T}$ denote the terminal productivity ratio, and $v$, the growth rate differential. Then,

$$
x_{T}=x_{0} \mathrm{e}^{v T} .
$$

The entries in table 6 indicate how long it will take with various growth rate differentials between eastern and western Germany to reach a specified degree of convergence (measured by the productivity ratio). Note that to fully converge in about 15 years would require a productivity growth differential of 0.08 . Assuming that western German productivity grows at 2 percent a year, eastern German productivity would have to grow by 10 percent per year. Is it possible to maintain such a growth rate?

The work of Barro and Sala-i-Martin-which is a systematic attempt

14. Barro and Sala-i-Martin (1991, p. 154).

15. Robert Barro, "Eastern Germany's Long Haul," Wall Street Journal, May 3, 1991, p. A10. 
Table 6. Time and Growth Rate Differentials Needed to Achieve Target Productivity Ratios

Years

\begin{tabular}{cccc}
\hline $\begin{array}{c}\text { Growth } \\
\text { rate } \\
\text { differential }\end{array}$ & \multicolumn{3}{c}{ Target productivity ratio } \\
\cline { 2 - 4 } & $x_{T}=0.8$ & $x_{T}=0.9$ & $x_{T}=1.0$ \\
\hline 0.01 & 98 & 110 & 120 \\
0.02 & 49 & 55 & 60 \\
0.04 & 25 & 28 & 30 \\
0.06 & 16 & 18 & 20 \\
0.08 & 12 & 14 & 15 \\
0.10 & 10 & 11 & 12 \\
\hline
\end{tabular}

Source: Authors' calculations based on the equation

$$
x_{T}=x_{0} e^{r T},
$$

where $x_{T}$ is the final productivity ratio and $v$ is the growth rate differential. The initial productivity ratio, $x_{0}$, is assumed to be 0.3 . See text for more information.

to analyze convergence-implies it is not possible. ${ }^{16}$ They find that growth advantages are small and diminish as productivity differences narrow. In their model, the growth rate differential, $v$, is negatively related to the gap between a region's productivity level, $Y$, and productivity in the benchmark region, $Y^{*}$ :

$$
v_{t}=-\beta \ln \left(Y_{t-1} / Y_{t-1}^{*}\right) .
$$

They estimate that $\beta$ equals 0.02 . Thus for an initial productivity ratio of 0.5 , they find an initial growth differential of 1.4 percent. Moreover, this already low growth rate declines over time as the productivity gap closes. Even with a smaller productivity ratio of 0.3 , the initial growth differential would be somewhat higher-but still only 1.8 percent. Eastern German growth would start off around 3.4 to 3.8 percent a year and then gradually fall off to the western German growth rate of 2 percent a year. As shown in table 6, with such small growth differentials, it takes more than a century to catch up.

The application of the cross-region evidence to the eastern German catchup is surprising because no room is left for special factors. At the very least, consideration could be given to an investment boom outside the sample experience. Surprisingly, Barro and Sala-i-Martin do not

16. Barro and Sala-i-Martin (1991). 
Table 7. Effect of Schooling and Investment on Productivity Growth in Selected Eastern European Countries

Percent per year

\begin{tabular}{lccccc}
\hline $\begin{array}{c}\text { Independent } \\
\text { variable }\end{array}$ & Bulgaria & CSFR $^{\mathrm{a}}$ & Poland & Hungary & $\begin{array}{c}\text { Eastern } \\
\text { Germany }\end{array}$ \\
\hline Productivity level & 0.07 & -0.11 & 0.18 & -0.02 & -0.11 \\
Schooling & -0.01 & 0.05 & 0.05 & -0.20 & 0.11 \\
Investment & -0.45 & -0.13 & -0.45 & -0.13 & 1.16 \\
Total & -0.39 & -0.19 & -0.22 & -0.35 & 1.15 \\
\hline
\end{tabular}

Source: Authors' calculations based on the equation

$$
\Delta y=-0.007 y+0.014 p+0.020 s+0.064 i
$$

where $y$ is the log of productivity (GDP per worker), $p$ and $s$ are primary and secondary school enrollment ratios (and are added together as the "schooling" variable in the table), and $i$ is the ratio of investment to GDP. All variables are expressed relative to the mean of the five countries. The coefficients are the averages of those obtained by Barro (1991, table 4). Labor force and GDP data (in order to get log productivity) are from Handbook of Economic Statistics, 1991 , and enrollment ratios are from UNESCO Statistical Yearbook, various issues. The authors assume that eastern German productivity equals that of the CSFR and assume investment ratios of 0.15 for Bulgaria and Poland, 0.20 for the CSFR and Hungary, and 0.40 for eastern Germany.

a. Czech and Slovak Federal Republic.

make allowances for this possibility, even as a conjecture. ${ }^{17}$ Of course, presenting a quantitative measure of the special "transition effect" is difficult, if not impossible.

A first attempt to add some extra factors is to use another model by Barro, in which growth in a cross section of countries is allowed to depend not only upon convergence, but also upon investment rates and country characteristics. ${ }^{18}$ Using an average of the coefficients obtained by Barro, the investment rate has a coefficient of 0.064 in a growth equation. This leads to a disappointing implication: even an extra 20 percentage points of GDP in investment yields only an additional 1.3 percentage points growth a year in productivity.

Consider an application of this equation to the relative performances of several Eastern European countries. Assume investment rates of 0.15 for Poland and Bulgaria, 0.2 for Hungary and the Czech and Slovak Federal Republic, and 0.4 for eastern Germany. In addition to letting initial per capita income levels determine convergence, let schooling and in-

17. In private communication, Robert Barro has said that he views the case of eastern German catch-up to be similar to that of the southern United States catching up with the North, Italy's South catching up with its North, or depressed regions of western Germany catching up with the more advanced regions. Barro observes that this perspective is optimistic because it assumes that ultimately, the convergence will be to a high level of per capita income like that of Western Europe, rather than to a low one like Romania's.

18. Barro (1991). 
Table 8. Investment and Productivity Growth in Selected High-Growth Countries Percent

\begin{tabular}{|c|c|c|c|c|c|c|c|}
\hline \multirow[b]{2}{*}{ Country } & \multirow{2}{*}{$\begin{array}{l}\text { Productivity } \\
\text { relative to the } \\
\text { U.S. level, } 1960^{\text {a }}\end{array}$} & \multicolumn{3}{|c|}{ Investment rate } & \multicolumn{3}{|c|}{ Gap closing } \\
\hline & & $1950 s$ & $1960 s$ & $1970 s$ & $1950 \mathrm{~s}$ & $1960 s$ & $1970 s$ \\
\hline Hong Kong & 24.2 & & 21.6 & 20.7 & & 10.4 & 17.7 \\
\hline Japan & 23.1 & 17.6 & 27.7 & 32.5 & 8.7 & 20.0 & 18.9 \\
\hline Korea & 11.1 & . & 17.0 & 29.3 & 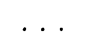 & 4.8 & 8.8 \\
\hline Singapore & 29.8 & $\ldots$ & 17.4 & 34.7 & $\ldots$ & 10.6 & 15.6 \\
\hline Taiwan & 11.7 & 10.8 & 17.0 & 27.3 & 3.9 & 7.3 & 13.0 \\
\hline Germany & 51.9 & 27.7 & 29.9 & 26.7 & 18.7 & 12.4 & 11.0 \\
\hline
\end{tabular}

Source: Authors' calculations from Summers and Heston dataset, Mark V. See Summers and Heston (1991).

a. The ratio of productivity in the country relative to productivity in the United States in 1960 is shown.

b. Gap closing is the percentage point reduction in the productivity gap over the decade.

vestment rates influence the relative performance. Table 7 shows the annual growth rate differentials relative to the average performance of the five countries, as predicted by the Barro model.

If transition and economic union result in a higher investment rate of 20 percentage points of GDP, the contribution to differential growth is barely above 1 percentage point a year. That is not negligible, but it clearly is not a mechanism that would move eastern Germany quickly away from the Czech and Slovak Federal Republic or Hungary. Accordingly, this evidence does not support predictions for rapid convergence between eastern and western Germany, but rather reinforces the cautious view expressed by Barro and Sala-i-Martin. ${ }^{19}$

\section{A Comparison with High-Growth Countries}

A different approach is to focus on the countries whose economies have performed the best and ask how much of the productivity gap they were able to close. Experiences of unusually high growth can be found in Germany during the early postwar period and in Asia, among such countries as Hong Kong, Japan, Singapore, South Korea, and Taiwan. Table 8 summarizes the investment rates and productivity improvements in selected high-growth countries.

19. Recalculating the growth differential assuming productivity in eastern Germany of 150 percent of the level for the Czech and Slovak Federal Republic reduces the figure to 0.9 percent per year. 
Examining the strongest, sustained growth experiences suggests that eastern Germany will not catch up in less than 20 to 30 years. In the best two decades, and even with very high investment rates, the best performers eliminated only 20 to 40 percent of the productivity gap. The simple average of the gap-closing rates shown in the table is 12.1 percentage points per decade. Even if we take the average of the best decade for each country-15.6 percent-eastern Germany still would need almost three decades to achieve 80 percent of western German productivity, starting from an initial gap of 70 percent.

\section{Special Factors}

To believe that eastern Germany can reach 80 percent convergence in as few as 15 years suggests an experience entirely unlike that of the most successful countries in the postwar period. What special factors could make such a performance possible? Unusually rapid catch-up in terms of per capita GDP or productivity would have to result from an outstanding performance of total factor productivity, an unusually rapid rate of capital accumulation, and any interaction between the two. Thus, one would look for aspects of the eastern German situation that make the experience uniquely favorable, even in the context of regional catch-up. ${ }^{20}$

We can divide the eastern German growth process into three phases. First, for given technologies and factor supplies, the shift to markets will bring about some improvement in productivity as labor hoarding is reduced, the worst inefficiencies are eliminated, and incentives are restored. The second stage in growth derives from the adoption of better technologies. The third stage follows from increases in factor supplies, principally the capital stock.

The first stage - the movement from the interior to the frontier of the production possibility set-produces similar productivity increases for all transition economies. By contrast, in eastern Germany, the extent of the adoption of new technology will far exceed the levels in the other

20. Some would see a parallel with the U.S. South and North after the Civil War. The two regions shared many common factors, including history and language-yet the South's catch-up was desperately slow. However, the precedent is really not relevant because eastern Germany is so small relative to western Germany and so near to it. Moreover, German communications and transport possibilities are a century more advanced. 
post-socialist economies. The difference partly reflects the benefits of common language. More importantly, the gains are a direct consequence of the Treuhand privatization strategy of selling enterprises to firms that operate in the same or a similar field.

Likewise, eastern Germany will attract a disproportionate share of investment in Eastern Europe. Among the reasons are the absence of political risk; the massive investment in infrastructure undertaken by the public sector; the sharp reduction in implementation problems because the administration has some market experience; the availability of inputs from Western markets; and free access to the European Community. In particular, the Feldstein-Horioka effect will not affect eastern Germany separately. ${ }^{21}$ In addition, eastern Germany is a natural location for western German firms to expand. Extensive subsidies to capital formation in the East-as high as 50 percent-will encourage a significant fraction of capacity expansion. Moreover, the less "green" attitudes of population and administration also will attract investment. The availability of a large pool of educated and generally skilled labor guarantees that capital accumulation will not run into bottlenecks for a long time.

Taken together, the growth potential in eastern Germany far exceeds the levels realistically attainable elsewhere in Eastern Europe. Apparently no precedent exists for such a potentially dramatic transfer of knowledge and skills. Accordingly, one cannot assert that simple osmosis will enable eastern German labor to increase productivity by, say, 20 percent. But it cannot be denied that significantly greater contact, exposure, and communication differentiate the eastern German case from standard convergence situations and can lead to dramatic productivity increases.

With so much attention being paid to the potential for growth in productivity during the transition, one must not overlook the down side. First, much of the existing capital stock has become economically obsolete. This is true for four reasons. First, the capital is antiquated. Second, it is unacceptable to a society concerned with environmental safe-

21. Feldstein and Horioka (1980) showed that national investment rates are determined (constrained) by national rates of saving. The issue here is whether for eastern Germany all-German saving, rather than simply eastern German saving, is the relevant constraint. For empirical evidence of the Feldstein-Horioka effect, see Dooley, Frankel, and Mathieson (1987). 
guards. Third, it may be unable to adjust to the factor proportions of a high-wage economy. Lastly, much of it is located in sectors or industries that are simply unviable. Eduardo Borensztein and Peter Montiel estimated that half to three-quarters of investment in the Czech and Slovak Federal Republic, Hungary, and Poland was wasteful. They conclude that "a large portion of the currently existing capital will be of little value in the context of a market economy. In the past, investment decisions were not made on the basis of profitability but instead were determined by central plan objectives, by the bargaining power of different enterprises, and other non-market criteria." 22 Clearly, that judgment is more appropriate for manufacturing capital stock than for housing and infrastructure.

The initial alignment to a market economy with a new set of prices and techniques implies an immediate reduction in GDP for two reasons: environmental problems and economic obsolescence (including the inability to sell products like the quaint and inefficient Trabant automobile at any price). In eastern Germany, the immediate drop in per capita GDP was 40 percent; this lengthened the minimum time until convergence. ${ }^{23}$ A further negative factor is the level of wages: this sets eastern Germany apart from the other transition economies. With wages on the way to parity, capital intensity is inevitably high; hence the contribution of investment to growth is commensurately low.

We make no attempt to quantify these factors, but they point in two directions. When we compare eastern Germany with other transition economies, on the one hand, eastern Germany gets all the advantages of unification and thus a far better shot at immediate productivity gains and extravagantly large rates of investment. On the other hand, eastern Germany will suffer disproportionately large initial losses because of tougher environment standards and a very sharp rise in wages. Most of the adjustment has and will take the form of job displacement. However, a good part of that unemployment and underemployment is resolved by emigration and commuting. The rest stands ready to serve as an ample supply of labor ready for investment-led output expansion.

All the Eastern European transition economies should reap a onetime productivity gain that derives from their unusual isolation. The

22. Borensztein and Montiel (1992, pp. 154-55).

23. Here is an instance where better GNP accounting, including environmental depreciation, would clearly make sense. 
more easily a country can gain access to and implement foreign knowledge and can attain an efficient international division of labor, the larger these gains will be.

In terms of income, eastern Germany is well on the way to convergence with western Germany. Massive transfers will sustain that result. However, in terms of productivity, the gap is still very large. Estimates of the investment required to achieve 80 percent equalization over the next decade are as large as DM 1 trillion. ${ }^{24}$ Any estimates are highly tentative: a higher growth rate of total factor productivity could sharply reduce investment requirements. But for the time being, the investment outlook is highly promising. Already, investment has increased from 24.8 percent of GNP in 1990 to 37.4 percent in 1991, worth some DM 72 billion.

In the immediate future, investment growth is likely at least to keep pace with GNP growth; thus for quite a while, record investment rates can be expected. In the next 15 years, chances are good that the productivity gap will narrow dramatically. However, the western German growth rate is likely to fall; this will contribute to convergence. Whether eastern Germany will catch up to France or proceed all the way to western German levels is impossible to predict. That eastern Germany will more closely resemble western Germany than Portugal is almost certain.

At this stage, productivity gains are achieved most easily by closing down highly inefficient operations. To the extent that liquidity loans or asset stripping sustains employment inefficiently, they also will perpetuate low levels of productivity. This consideration highlights the conflict between achieving high productivity and achieving high employment. High productivity jobs can come from greenfield investments. Service sector growth adds to employment, but not at a very high level of productivity. Somewhere in between in terms of productivity growth is plant restructuring (broadly interpreted to include improvements in technology and investment in plant and equipment, as well as human capital formation). The interesting question is how much of the gain in output per worker during the next decade will come from investment and how much from the residual. Unification is more likely to succeed if unusual reserves of productivity growth exist that can be unlocked without high rates of investment. 
In the short run, productivity growth will do relatively little for employment (except by expanding the service sector). This conclusion suggests that migration and commuting should not be viewed as terrible outcomes; rather, they should be encouraged to equalize incomes more rapidly, with less unemployment. The simple fact is that another 1 million to 2 million workers moving West would solve the bleak employment outlook in the East. In the past two years alone, the West created almost that many new jobs by running a high-pressure economy.

\section{The Burden of Unification on Western Germany}

Unification has three clear implications for western Germany. First, burdens on taxpayers will be significant. Second, skilled labor will be plentiful and hence tension between a union-dominated high wage strategy and a full employment strategy will increase. Of course, increased labor market competition will be a clear plus in controlling inflation. Third, investment in western Germany certainly will fall unless major budget efforts are forthcoming or Feldstein-Horioka effects are not present at all. The decline in investment in turn puts in question Germany's ability to sustain high and rising real wages. Some have suggested that a peace dividend should permit a rise in after-tax wages, but such a dividend is hard to find.

\section{Short-run Effects}

Unification came at the tail end of a boom and moved the western German economy into a situation of overheating and inflation. Unification and the transition increased demand for western German goods. This extra impetus helped push capacity utilization to a peak for the decade. Meanwhile, the unemployment rate fell to a level not seen in a decade-despite large immigration. Table 9 summarizes macroeconomic conditions in western Germany.

Unions responded to the overheating labor market with demands for wage increases in excess of productivity growth. Inflation accelerated sharply and the Bundesbank raised interest rates sharply, as expected. The reduction of extra demand stimulus from the East, sustained tight money, and the onset of a solidarity tax (a 6.5 percent income surtax 
Table 9. West German Macroeconomic Indicators, 1979-93

Percent per year, except where indicated

\begin{tabular}{lcccccc}
\hline \multicolumn{1}{c}{ Indicator } & $1979-89$ & 1989 & 1990 & 1991 & 1992 & 1993 \\
\hline Growth & 1.8 & 3.8 & 4.5 & 3.2 & 1.8 & 2.5 \\
Unemployment rate & 5.1 & 5.6 & 5.1 & 4.6 & 5.0 & 5.1 \\
Employment growth & 1.3 & 1.3 & 2.6 & 2.1 & 1.0 & 1.0 \\
Inflation & 2.9 & 3.2 & 3.4 & 4.4 & 4.5 & 3.9 \\
$\begin{array}{l}\text { Budget deficit } \\
\quad \text { (percent of GDP) }\end{array}$ & -2.1 & 0.2 & -2.5 & -3.7 & -3.5 & -2.9 \\
\hline
\end{tabular}

Source: OECD Main Economic Indicators: Historical Statistics and OECD Economic Outlook, December 1991. Figures for 1992 and 1993 are estimates.

scheduled to expire this year) now combine to slow down the German economy - and with it the economy of Europe. In Germany, the boom that preceded these events and high inflation make high interest rates and the slowdown far less of a problem than they are for the rest of Europe.

In budget terms, the starting point for the financing of unification was exceptionally favorable. Germany had worked during the 1980 s to improve its fiscal position; the budget deficit had been eliminated and the debt ratio had started declining from a level that was not high to start with. Figure 2 presents expected public debt ratios in Germany and the United States. In Germany, the fiscal outlook has deteriorated for the foreseeable future as a result of unification. Transfer payments will continue for quite a while. Moreover, the more ambitious the wage push in the East, the larger the deficits will be. In fact, Germany's deficits risk building up a debt curve not unlike that of the United States in the 1980s.

Unification affects the capital market two main ways: through budget deficits resulting from transfer payments, and through investment outlays associated with improving infrastructure and business formation in the East. Because households and firms in the East are not saving, unification requires massive borrowing through the western German capital market. The capital market pressure helps explain the presence of high long-term real interest rates implicit in nominal yields of 8 percent and a declining inflation rate. In part because of pervasive subsidization of investment, especially in the East, these high long-term rates have not yet slowed investment to any major extent. So far, a major deterioration in the current account has financed the increase in demand. Clearly, 
Figure 2. Public Debt Ratios in Germany and the United States, 1980-2002

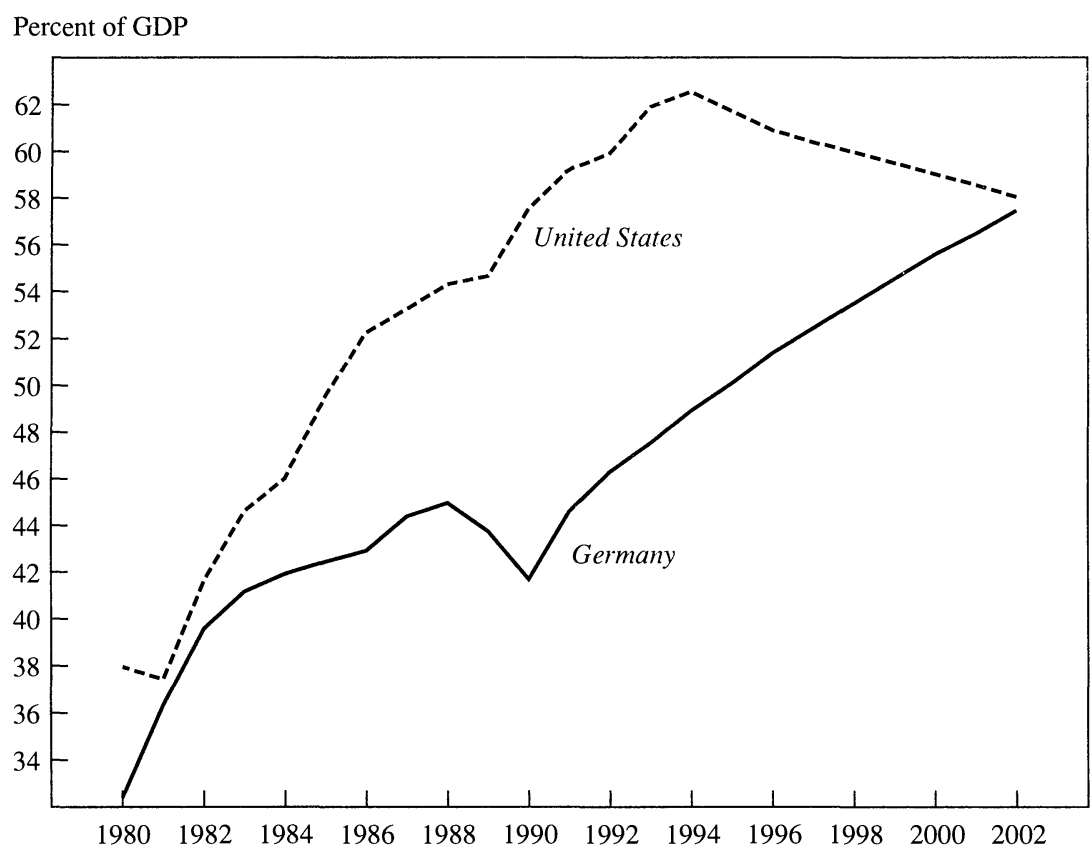

Source: Figures for 1980-1992 are from OECD Economic Outlook, December 1991. Thereafter, the debt ratio is 1/1.06 times the previous year's debt ratio plus the deficit ratio. For Germany, the authors assume a deficit ratio of 3.5 percent of GDP and 5 percent nominal income growth per year. For the United States, nominal income is assumed to grow by 5 percent per year. For 1992-97, U.S. deficit ratios published in the Congressional Budget Office January 1992 report, "An Analysis of the President's Budgetary Proposals for Fiscal Year 1993," are used. Thereafter, the U.S. deficit ratio is assumed to be 2.8 percent of GDP.

though, capital and labor markets are challenged beyond their capacity to deliver on all promises and expectations. As Hans Mundorf argued in a German newspaper in March 1992, "tax reduction, debt consolidation, stable money, financing unification, moving the parliament and government back to Berlin, compensating Bonn, feeding the world, expanding social and environmental protection; all that cannot be done at one and the same time because it cannot be financed. As long as policy makers don't set priorities, nobody has a right to expect discipline in wage settlements." 25

25. Hans Mundorf, "Im Milliardenrausch," Handelsblatt Wirtschafts-und Finanzzeitung, March 13, 1992 (reprinted in Deutsche Bundesbank, "Auszüge aus Presseartikeln," March 18, 1992, and translated by the authors). 
Figure 3. Goods Market Equilibrium in Germany and the Rest of the World

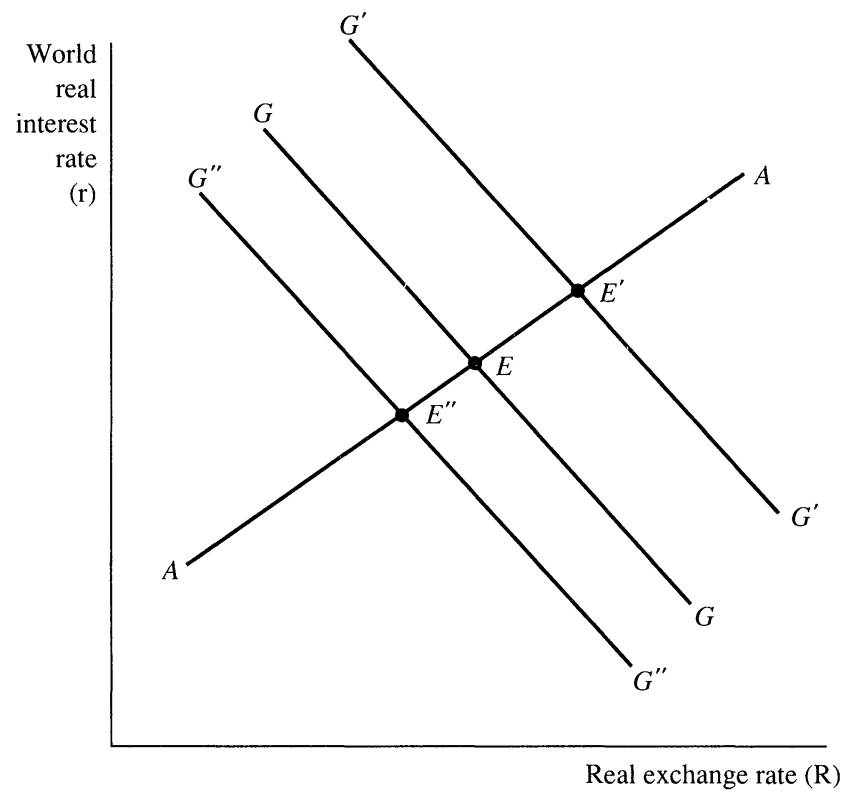

\section{Evaluating Longer-run Effects}

A starting point for generating and examining scenarios and evaluating policy is a classical full employment setting. Figure 3 examines the goods market equilibrium for Germany and the rest of the world. The transfer between eastern and western Germany-with consumption smoothing in the East and the incentive to invest created by eastern opportunities-leads to a world increase in demand for goods, focused on goods from Germany.

In Figure 3, the line labelled $G G$ shows the market equilibrium for goods in Germany; line $A A$ shows equilibrium in the rest of the world. Equilibrium in each market depends upon the world real interest rate, $r$, and the real exchange rate, $R$, defined as German prices relative to foreign prices in a common currency. The standard model predicts a real appreciation (a rise in $R$ ) in Germany, a rise in the world real interest rate, and a German current account deficit. ${ }^{26}$ This is shown by the shift

26. See also Alexander and Gagnon (1990) and the simulations reported in Lipschitz and McDonald (1990). 
from equilibrium point $E$ to $E^{\prime}$. Over time, German relative potential output expands as labor becomes employed and capital accumulates. At this stage, a world excess supply for German goods develops, along with increased saving. This is shown by the shift to longer term equilibrium at $E^{\prime \prime}$. In the long run, the real exchange rate depreciates (relative to $E$, and especially $E^{\prime}$ ), real interest rates decline toward their initial level, and the German trade balance improves to generate debt service.

To date, the model has only been partly successful in explaining the short run effects of unification on the western German economy. Real interest rates have risen and Germany's current account has deteriorated. But relative prices have not changed to any extent, mostly because the European Monetary System has made partner countries peg exchange rates and suffer a slowdown in demand during periods of high interest rates. ${ }^{27}$ In Germany, by contrast, the lack of real appreciation in the currency has translated into a boom.

Looking ahead, the challenge for German economic policy is to absorb a triple shock: financing of consumption smoothing in the East; investment in the East; and an increase in labor supply in the connected labor markets. Incomes policy and fiscal policy are the chief tools available to cope with these challenges. One strategy would be to raise taxes sharply, cut domestic spending in the West, and thus finance both the transfers and investment at an unchanged real exchange rate and real interest rate. Another strategy (in the extreme) would be pure debt finance, including crowding-out by real appreciation and high real interest rates. A third strategy would take a middle road, using incomes policy, some taxation, and some borrowing to avoid excess burdens of unification.

What should be the public policy toward financing the East: debt or taxes? The correct view is that rebuilding eastern Germany is an investment project-including part of the consumption smoothing in the East financed by transfers. Thus increasing taxes moderately and predominantly using debt finance is the correct approach. Over time, the debt ratio will increase, as shown in figure 2 above, but it will settle down in a decade or so as transfers come down. The situation would look quite a bit like that in the United States in the 1980s. In both cases, the budget has financed an increase in consumption. The similarity goes further: the

27. See Adams, Alexander, and Gagnon (1992). 
reduction of transfers to eastern Germany is nowhere on the horizon, just as there is no early prospect of raising taxes (or cutting spending) to contain the U.S. budget deficit.

Of course, some differences exist. First, western German private saving rates have not declined; thus capital formation has not suffered as much as in the United States. Second, even transfer payments can be interpreted as part of an investment in a political transition that avoids divisive politics and fosters a stable business environment.

There is little doubt that economic prosperity would happen sooner in the East if a larger fraction of transfers were saved and invested. But even that argument must not be carried too far. Part of the reconstruction of the East must be the creation of a service sector. It is hard to see how a service sector would come into existence without a substantially increasing purchasing power in the East.

It remains to be seen how saving in the West and in the East will evolve as the economic prospects of the next decade come more sharply into focus. In the West, the prospect of higher taxes is clear. In the East, saving should increase as the catch-up on durables that has taken place winds down. ${ }^{28}$ Both these developments will help limit the crowding out associated with the budget deficits. But they may not be enough to offer the assurance that high levels of investment can exist in both the East and in the West.

\section{Policy Prescriptions}

How can Germany best cope with the reconstruction? ${ }^{29}$ One priority is to run a high-pressure economy in the West. That means maintaining high capacity utilization; this would serve as an incentive to create new capacity, much of it in the East. A high-pressure economy also would attract migrants and immigrants from the East. That is presumably the best way to turn eastern Germans rapidly into high productivity workers and taxpayers.

28. Western Germany offers an interesting test of Ricardian equivalence. Because the West has borne a large share of the cost, consumption should have declined-unless one wants to argue that improved security and future peace dividends sustain the level of consumption.

29. See also Siebert (1991) and Sinn and Sinn (1991). 
The essential support for such a strategy must come from unions. A high-pressure economy definitely needs an incomes policy. In the West, unions must agree to wage demands in line with productivity growth so that there is no need to fight inflation with high interest rates and unemployment. Why should unions agree to control wages? Because the alternative is worse: they would have to pay far higher taxes in the future because the East would remain a welfare state, rather than becoming a productive region. Western German union members as taxpayers cannot escape the burden of the East: either they must allow eastern Germans to compete with them in the West or else they must pay for eastern Germans to stay in the East. Union members ought to have a strong interest in minimizing the cost of the operation.

A special difficulty arises from the need to finance increased investment in the East while consumption is booming. To complicate matters further, investment in the West cannot fall too much without causing western Germany to lose competitiveness in world markets. If Feldstein-Horioka effects are not important, so that increased consumption spills over into the current account rather than crowding out investment, further fiscal changes may not be needed. By contrast, if higher consumption falls substantially on domestic goods, and if real appreciation is resisted for sectoral reasons, then fiscal tightening cannot be avoided.

The likely course is that the consumption needs of the East, infrastructure investment, and investment in business reconstruction will amount to a bill too high to be compatible with strong performance in Germany's traded goods sector. Either real wages will stop growing for a while and create a cushion of profits and investment, or crowding-out will turn into a fight over income shares that will derail an already difficult situation. Thus unions bear a critical responsibility in spreading the costs of adjustment over time with minimal crowding out; this would present the best prospects for sustainable real wage growth.

In eastern Germany, a very different approach is needed. Sustained subsidization on the job is undesirable because it demoralizes workers and retards the urgent task of modernization and restructuring. A better approach is to pay unemployment compensation, provide education and training premiums, and create financing vehicles for small businesses. Needless to say, stabilization of the wage level in the East—or at least a wage policy linked to productivity-would help on all fronts. 
One further avenue must be explored. The end of communism and unification surely changes the security outlook and dramatically reduces the need for a strong defense posture. An immediate, major scaling down of military expenditures and a replacement of the draft by a volunteer army would release resources and reduce budget pressures. Unification, rather than imposing a large tax on the West, could then yield a gain in income. However, without a major reconsideration of defense that leads to substantial savings, unification will place a large economic cost on the West for an extended period. 


\section{Comments and Discussion}

Lewis Alexander: I may not be the best person to comment on this paper because my views on this topic are very close to those of the authors. I have a few disagreements with the authors regarding economic developments to date and their policy prescriptions. The bulk of my comments, however, will attempt to flesh out the argument that eastern German income will converge to the western German level relatively quickly.

Rudiger Dornbusch and Holger Wolf argue that the failure to write off the old debts of eastern German state-owned enterprises was a mistake. Such debts can cause two problems in the transformation of Soviet-style et-style planned economies. As the primary asset on the consolidated balance sheet of the banking system, their dubious credit quality can be a major obstacle to improving the performance of the financial system. They also can complicate the task of privatization.

In other formerly socialist countries, these problems have been allowed to persist because they are expensive to resolve. A general writedown of enterprise debts must entail either the imposition of losses on the main creditors of the banking system (that is, depositors) or the issuance of new government liabilities to replace the bad debts at a time when fiscal consolidation is probably the primary policy goal.

However, the special circumstances of economic transition in eastern Germany have meant that these problems have not arisen there. Monetary union was implemented in such a way that the government of the Federal Republic effectively guaranteed the liabilities of the German Democratic Republic's banking system. ${ }^{1}$ Moreover, western German

1. See "The Monetary Union with the German Democratic Republic," Monthly Report of the Deutsche Bundesbank, July 1990, pp. 13-28. 
banks rapidly took over most banking activity in eastern Germany. It also is difficult to make the case that these debts were a major obstacle to privatization. It is certainly true that they have complicated the task of the Treuhand at a time when it was overextended. But the Treuhand has taken over the debts of enterprises when that was necessary to complete a sale, and the Treuhand has not lacked financial resources.

Dornbusch and Wolf say relatively little about the controversy raised by George Akerlof and his coauthors over the rapid increase of eastern German wages. ${ }^{2}$ The essential question is why eastern German workers demanded large wage increases in the face of a dramatic decline in the demand for eastern German output. Dornbusch and Wolf cite unions and geography as the principal culprits. But the role of the government is probably just as important. First of all, the extension of generous social insurance schemes to eastern Germany has largely insulated eastern German incomes from the sharp decline in the demand for eastern German labor. In addition, the German government initially was the principal shareholder of most eastern German firms. Wage negotiations were fundamentally imbalanced, not because of union intransigence, but because management (that is, the German government) was firmly committed to a rapid increase in incomes in eastern Germany.

This also helps explain why the wage subsidy scheme proposed by Akerlof and others was not more widely considered in Germany. In principle, one could imagine the German government pursuing structural policies aimed at generating productivity growth in eastern Germany, while at the same time implementing a policy aimed at restraining wage growth as an obstacle to adjustment. But such a combination of policies, with its distinctions between means and ends, was probably politically infeasible for a government that remains committed to raising income levels in eastern Germany.

Dornbusch and Wolf's analysis of how the costs of unification should be financed ignores the impact of German fiscal policy on other countries, particularly those in the European Monetary System (EMS). German unification generated a demand shock that was concentrated in Germany. German monetary policy tightened in response. Other EMS countries were affected through two channels. German imports increased sharply, but they also had to increase interest rates to maintain

2. Akerlof and others (1991). 
their nominal exchange rates vis-à-vis the deutsche mark. The net effect may have been negative. ${ }^{3}$ The trade balances of the other EMS countries with Germany have improved significantly, but their total trade balances have declined. Part of this discrepancy is caused by the increased cost of oil imports. But it also suggests that the negative impact of higher EMS interest rates, and the resulting appreciation of EMS currencies, on trade flows has largely offset the direct stimulus generated by stronger German imports. This, in combination with the negative impact of higher interest rates on domestic demand, suggests that German unification has depressed growth in other EMS countries.

Clearly a moderation of wage demands by western German unions, which Dornbusch and Wolf advocate, would help to mitigate the negative impact of unification on other EMS countries. But German fiscal policy has made this problem worse. The decision to finance unification largely with borrowing has intensified the demand shock concentrated on Germany and with it, the negative spillovers to other EMS countries. If German policymakers take into account the impact of their policies on other countries, as surely they should, then the case for borrowing to finance unification is far from overwhelming.

On the question of convergence, Dornbusch and Wolf identify three sources of productivity growth: the introduction of market incentives; the transfer of knowledge and technology; and investment. The authors argue that productivity growth in eastern Germany is likely to be faster than in other reforming, formerly socialist economies. They stress the fact that the transfer of knowledge and technology will be more rapid because of the high level of western German investment in eastern Germany, as well as cultural and linguistic linkages to western Germany. Moreover, they argue that investment in eastern Germany will not be constrained by Feldstein-Horioka effects. I would like to bolster the authors' basic conclusion by presenting evidence that the potential productivity gain from the introduction of market incentives is large. I will also offer some simple quantitative evidence about the potential contribution of investment to a rapid convergence.

3. Two factors dampened the negative impact on Germany's EMS trading partners. The increasing integration of European goods markets enhanced the positive impact generated through German imports. Interest rate differentials between Germany and other countries have declined over the last two years; this has dampened the impact of tighter German monetary policy. 
The introduction of the incentives of a market system in eastern Germany is likely to generate a significant increase in productivity. Another way of looking at this question is to ask whether it is reasonable to assume that the inefficiencies of the old socialist system manifested themselves only in fixed capital. If the answer to this question is yes, then the per capita output deficit in the GDR was due solely to the low level and poor quality of investment. But surely the lack of appropriate incentives in the old system caused resources other than capital to be used inefficiently. The elimination of these other inefficiencies, which can be corrected without further investment, is a source of rapid productivity growth.

A precedent for rapid convergence of this type exists in the economic reconstruction of West Germany following World War II. ${ }^{4}$ During the first phase of the postwar economic "miracle," from roughly 1947 to 1950 or 1951, economic activity increased extremely rapidly as output returned to prewar levels. But the utilization of inputs, measured in conventional ways, changed little during this period, implying dramatic increases in productivity. In first few years following the end of the war, economic activity was held down by a variety of factors: the absence of money as a means of exchange because of a severe repressed inflation; an outmoded system of economic controls; and fundamental uncertainty over basic property rights and the economic system to be adopted in postwar West Germany. ${ }^{5}$ The productivity gain observed in West Germany between 1947 and 1950 - roughly 50 percent in the industrial sector-can be attributed to the elimination of these factors. ${ }^{6}$

In postwar West Germany, it was relatively easy to rectify these problems-and reap the resulting increase in productivity-because the essential framework of a market economy (that is, a system of commercial law and private ownership of most economic assets) still existed. There is no question that it will take longer to realize the analogous gains in productivity in eastern Germany-and other reforming countries because the institutional transformation that is needed is so much more

4. The discussion of the postwar economic performance of western Germany is based on Alexander (1991).

5. War damage was relatively unimportant. Wartime additions to the capital stock far outweighed war damage and allies' dismantling.

6. It is worth noting that the allied occupation of West Germany delayed recovery. In spite of similar declines, industrial production in West Germany did not return to prewar levels until 1950, compared with 1947 in Italy and 1948 in France. 
extensive. However, that does not imply that such gains will not ultimately be achieved.

Some data already indicate that productivity is increasing rapidly in eastern Germany. Output per hour in the industrial sector is reported to have increased 76 percent between January and December of $1991 .^{7}$ This increase in productivity was accounted for almost exclusively by a decline in hours worked, with virtually no change in the level of output. Undoubtedly some of the decline in hours worked was merely a delayed response of labor demand to the sharp drop in eastern German industrial production in the second half of 1990 . But it also may be the first concrete evidence of the benefits of economic reform in eastern Germany. The fact that output did not increase must at least partly reflect the combination of the extreme openness of the eastern German economy and the rapid increase in wages. In fact, the increase in labor productivity just offset the increase in wages, so that unit labor costs were little changed ${ }^{8}$ Had wages not increased so much, and or had some mechanism such as an exchange rate depreciation or tariff been available to divert eastern German demand away from foreign products, surely this increase in productivity would have resulted in an increase in output.

Dornbusch and Wolf point out that investment in eastern Germany need not be constrained by Feldstein-Horioka effects and thus a rapid investment-driven convergence of income levels is possible. However, the authors make no attempt to quantify this effect. I would like to offer some very tentative quantitative evidence on this point.

First of all, investment in eastern Germany is increasing rapidly. Real gross fixed investment is estimated to have increased 18 percent in 1991; it is expected to increase 26 percent in 1992. Perhaps the best indicator is the level of investment per employee in eastern Germany compared with western Germany. This measure increased from 37 percent in 1990 to 52 percent in 1991 ; it is expected to increase to 78 percent in $1992 .{ }^{9}$ Western German firms operating in eastern Germany, which are expected to account for about half of all investment in eastern Germany, are expected to invest roughly the same amount per employee in both regions this year. ${ }^{10}$

7. See Wochenbericht, 12-13/92 (March 19, 1992).

8. See Wochenbericht, 12-13/92 (March 19, 1992).

9. See Wochenbericht, 16-17/92 (April 16, 1992).

10. See ifo Schnelldienst 6/1992. 
If investment per employee in eastern and western Germany remains the same for ten years, eastern German labor productivity will be 84 percent of the western German level at the end of the period. ${ }^{11}$ In this back-of-the-envelope calculation, it is assumed that no autonomous productivity increase occurs due to the transition to a market system. Furthermore, rapid capital accumulation in eastern Germany will mean that the vintage of the eastern German capital stock will be considerably newer than that of western Germany. This also may increase productivity growth in eastern Germany if a significant portion of technical change is embodied in the capital stock, as recent work for the United States suggests. ${ }^{12}$

In a recent paper, two colleagues and I used a medium sized macroeconomic model of the global economy to simulate the impact of German unification. ${ }^{13}$ In doing so, we assumed that investment in eastern Germany will be determined by the same underlying factors and parameter estimates as investment in western Germany. The only difference between eastern and western Germany in this simulation is in their initial capital labor ratios. The basic structure of the model-the Federal Reserve's MX3 model-is analogous to the basic structure of the Barro and Sala-i-Martin model: aggregate supply is modeled using a Cobb-Douglas production function, and both consumption and investment are based on forward-looking, model-consistent expectations. The simulations estimate the rate of eastern German convergence under conditions of extreme openness. Eastern German investment is assumed to have the same access to German savings as investment in western Germany. In addition, the German economy is assumed to be open in the conventional sense. Unification generates a sharp real appreciation of the deutsche mark and a sharp decline in the German current account. The basic result is that output per worker in eastern Germany converges to the western German level at an average rate of 14 percent over the first 15 years, compared with Barro and Sala-i-Martin's estimate of a 2 percent convergence rate across a cross section of regions. This suggests that a rapid rate of convergence in eastern Germany, driven by invest-

11. Initially eastern German labor productivity is assumed to be one third of western German levels. Other structural parameters are taken from Adams, Alexander, and Gagnon (1992).

12. See Greenwood, Hercowitz, and Krusell (1992).

13. See Adams, Alexander, and Gagnon (1992). 
ment, does not require implausible movements in global savings and investment balances.

Dornbusch and Wolf cite a number of differences between the eastern German case and those analyzed by Barro and Sala-i-Martin. One factor that they do not mention is the role of the German government. Government transfers to eastern Germany are expected to be about 5 percent of German GNP this year, about one-third of which will support investment. ${ }^{14}$ It seems likely that the supplies of public fixed capital in the two regions of Germany will converge more rapidly than in the other cases analyzed by Barro and Sala-i-Martin.

\section{General Discussion}

Much of the discussion centered on the sources of economic growth, as well as on the relevance of general models and evidence on convergence to the special case of convergence between the "two" Germanys. Susan Collins pointed out that in the case of eastern Germany, not only is a reallocation of factors taking place, but a rapid transfer of technology is also occurring, which the standard models do not assume. This may result in much more rapid convergence than the cross-country studies suggest. Collins added that part of the convergence might come from a slowdown in growth in western Germany, as its capacity to absorb immigrants from the East diminishes. Holger Wolf found it useful to distinguish three sources of convergence: first, the move to the productionpossibility frontier with existing factor supplies; second, the replacement of existing factor supplies with state-of-the-art technology; and third, the expansion of factor supplies, through high investment rates. The first source would be common to all the centrally planned economies now in transition to market economies. However, eastern Germany is likely to have a substantial advantage in the second and third areas because of its special access to western German resources.

Panelists suggested several possible precedents. William Nordhaus remarked that convergence was relatively slow in the postbellum growth of the northern and southern states of the United States. Stanley Fischer suggested that a more relevant example of integration might be

14. See "Public Financial Transfers to Eastern Germany in 1991 and 1992," Monthly Report of the Deutsche Bundesbank, March 1992, pp. 15-22. 
the rapid removal of barriers between Israel and the occupied territories after the 1967 war. Initially, convergence was rapid, largely as the result of labor migration. Per capita income in the occupied territories nearly doubled in five years. Then convergence essentially stopped. Robert Shiller suggested that recovery from the 1906 earthquake in San Francisco might also provide evidence of catch-up time between two closely related entities when the capital stock of one had been destroyed.

Shiller questioned the appropriateness of using models that typically assume low labor migration when the relatively small geographic size of eastern Germany and the location of Berlin as an enclave in its center mean that most workers can commute to work in the western sections without changing their place of residence. Thus the reallocation of labor should occur much faster in the case of German unification than a standard regional model would predict. Wolf observed that these same considerations suggest that a low-wage strategy for eastern Germany would have been unsustainable. Henry Aaron, following the older development literature, suggested that the key issue in the convergence process is how long eastern Germany will take to reach western capital-labor ratios; if capital-labor ratios equalize, so will the other important economic variables. However, Martin Baily added that the standard analysis is not a good guide to how quickly any of this would happen in Germany. There, the process of economic development has to do mostly with the shift from a largely agricultural, primitive economy toward a more modern commercial economy, rather than with conversion of a more industrialized, but centrally planned, economy to a market economy. Baily also noted that, while it might appear from the high rate of investment in eastern Germany that the return to capital is high, most of the investment is flowing into residential construction, rather than into industrial capital.

Lawrence Katz suggested that German unification will provide a test case for two different views of how rapid wage increases will affect the transition. The first, the "Charles Murray" view, says that simultaneously paying people higher wages and increasing the generosity of unemployment insurance will have little effect on productivity. Thus increases in real wages in the East will lead to persistent unemployment and require western Germany to transfer resources to the East for a long time. The second view, the more optimistic "Akerlof-Yellen" view, sees higher wages as a type of gift-exchange that will call forth much greater 
work effort and produce much more rapid convergence. Katz suggested that Puerto Rico and the north of England are persistently depressed regions consistent with the first view. He argued that it remained to be seen whether eastern Germany would fulfill the optimistic Akerlof-Yellen expectations. 


\section{References}

Adams, Gwyn, Lewis Alexander, and Joseph Gagnon. 1992. "German Unification and the European Monetary System: A Quantitative Analysis." Unpublished paper, Washington: Board of Governors of the Federal Reserve System (February), forthcoming in Journal of Policy Modelling.

Akerlof, George A., and others. 1991. "East Germany in from the Cold: The Economic Aftermath of Currency Union." BPEA, 1:1991, 1-87.

Alexander, Lewis. 1991. "Radical Economic Reform in Germany, 1948 and 1990: Similarities, Differences, and Lessons for the Soviet Union.' Unpublished paper, Board of Governors of the Federal Reserve System (June).

Alexander, Lewis S., and Joseph E. Gagnon. 1990. "The Global Economic Implications of German Unification." International Finance Discussion Paper 379. Washington: Board of Governors of the Federal Reserve System (April).

$\rightarrow$ Barro, Robert J. 1991. "Economic Growth in a Cross Section of Countries." Quarterly Journal of Economics 106: 407-43.

Barro, Robert J., and Xavier Sala-i-Martin. 1991. "Convergence across States and Regions." BPEA, 1:1991, 107-58.

Borensztein, Eduardo, and Peter J. Montiel. 1992. "Savings, Investment, and Growth in Eastern Europe." In Central and Eastern Europe Roads to Growth, edited by Georg Winckler. Washington: International Monetary Fund and Austrian National Bank.

Bureau of Labor Statistics. 1991. "International Comparisons of Hourly Compensation Costs for Production Workers in Manufacturing, 1975-90." Report 817. Washington: U.S. Department of Labor (November).

$\rightarrow$ Dooley, Michael, Jeffrey Frankel, and Donald J. Mathieson. 1987. "International Capital Mobility: What Do Saving-Investment Correlations Tell Us?" IMF Staff Papers 34: 503-30.

$\rightarrow$ Feldstein, Martin, and Charles Horioka. 1980. "Domestic Saving and International Capital Flows.” Economic Journal 90: 314-29.

Franz, Wolfgang. 1991. “German Labour Markets after Unification.” Unpublished paper, University of Konstanz (October).

Greenwood, Jeremy, Zvi Hercowitz, and Per Krusell. 1992. "Macroeconomic Implications of Capital-Embodied Technological Change.' Unpublished paper, University of Western Ontario (March).

Lawrence, Robert J., and Charles L. Schultze, editors. 1987. Barriers to European Growth: A Transatlantic View. Washington: Brookings.

Lipschitz, Leslie, and Donogh McDonald, editors. 1990. German Unification: Economic Issues. Washington: International Monetary Fund.

McDonald, Donogh, and Günther Thumann. 1990. "Investment Needs in East Germany." In German Unification: Economic Issues, edited by Leslie Lipschitz and Donogh McDonald. Washington: International Monetary Fund. 
Scheremet, Wolfgang, 1992. "Der Arbeitsmarkt in Deutschland." Wochenbericht 5-6/92 (Deutsches Institut für Wirtschaftsforschung, January 30, 1992). Scheremet, Wolfgang, and Jürgen Schupp. 1992. "Pendler und Migranten-Zur Arbeitkräftemobilität in Ostdeutschland." Wochenbericht 3/92 (Deutsches Institut für Wirtschaftsforschung, January 17, 1992).

$\rightarrow$ Siebert, Horst. 1991. "German Unification." Economic Policy 6: 289-340.

Sinn, Gerlinde, and Hans-Werner Sinn. 1991. Kaltstart: Volkswirtschaftliche Aspekte der deutschen Vereinigung. Tubingen: J. C. B. Mohr.

$\rightarrow$ Summers, Robert, and Alan Heston. 1991. "The Penn World Table (Mark 5): An Expanded Set of International Comparisons, 1950-1988." Quarterly Journal of Economics 104: 327-68.

Wochenbericht (Weekly Report). Various issues. Berlin: Deutsches Institut für Wirtschaftsforschung. 